\title{
Image Rights: Exploitation and Legal Control in English and Hungarian Law
}

\author{
By Corinna CoOrs* and Péter Mezei**
}

\begin{abstract}
In the past decades due to changed technical advances, features of the personality have become economically exploitable to an extent not previously known. Pop stars, TV celebrities as well as famous athletes have sought protection against the commercial use of their images, names and likenesses without their consent. ${ }^{1}$ Despite the economic value of personality and image rights, there is currently no international standard or agreed legal concept for recognising an image right. While many jurisdictions, for example, the US, Germany, France and Hungary offer express statutory protection against the unauthorised commercial use of an individual's image by a third party in the context of publicity or personality rights, English law provides no cause of action for the infringement of image rights as such. Although a celebrity may currently obtain protection through various statutory and common law rights, such as the developing law of privacy, trade mark law breach of confidence and, in particular, the tort of passing off, none of these rights were designed to protect image or personality rights. ${ }^{2}$ In this context, this article explores the potentially enforceable rights, their benefits and practical strategies to protect name and image rights in the $\mathrm{UK}^{3}$ and Hungary.
\end{abstract}

Keywords: image rights, personality rights, privacy

\section{INTRODUCTION}

The article is structured as follows. Firstly, it will be introduced how image rights might or might not be protected and exploited under the doctrine of passing off, trademark law and privacy law of the United Kingdom. Secondly, the regulations of the Hungarian Civil Code ${ }^{4}$ on image rights will be covered, as well as multiple other tracks of protection and exploitation under the law of Hungary, including copyright and trademark law. Finally, the main features - similarities and differences - of the two legal systems will be compared.

* Associate Professor, Ealing School of Law, University of West London, United Kingdom. E-mail: corinna.coors@uwl.ac.uk

** Associate Professor, Institute of Comparative Law, Faculty of Law, University of Szeged, Hungary. Adjunct Professor (dosentti) of the University of Turku, Faculty of Law, Finland. He is a member of the Hungarian Council of Copyright Experts. E-mail: mezei.@juris.u-szeged.hu

1 See in the UK for example Fenty \& Ors v Arcadia Group Brands Ltd \& Anor [2015] EWCA Civ 3; Irvine v Talksport [2002] 2 All ER 414 (Laddie J), [2003] EWCA Civ 423; in Germany, for example: Boris Becker - BGH, 29 October 2009, I ZR 65/07; Marlene Dietrich, BGH, 1 December 1999, I ZR 49/97, BGHZ 143, 214.

2 Waelde, Laurie (2014) 803.

3 Blum, Ohta (2014) 137-147.

${ }^{4}$ Act V of 2013 on the Civil Code. (Hereinafter: HCC 2013.). 


\section{IMAGE RIGHTS IN THE UK}

\subsection{Definition of the Term "Image Right" in the UK}

An image right can be defined as a term used to describe rights that individuals have in their personality, which enables them to control the exploitation of their image..$^{5}$ A person's image is to be understood in broad terms and may generally include name, voice, signature, likeness and photographs and illustrations of the personality. In relation to the protection of one's personal image, the European Court of Human Rights (ECtHR) confirmed in the second Hannover v Germany judgment that the image is "one of the chief attributes of (...) personality, as it reveals the person's unique characteristics and distinguishes the person from his or her peers. The right to protection of one's image is thus one of the essential components of personal development. It mainly presupposes the individual's right to control the use of that image including the right to refuse publication thereof." 6

However, as noted above, English courts have traditionally been reluctant to expressly recognise personality and publicity rights and to provide protection for vague concepts such as names, likenesses or popularity. Celebrities can currently seek protection through the various existing intellectual property and, in particular registered trademark rights or common law passing off claims although these remedies often lack clarity and transparency. ${ }^{7}$ In the absence of a formal legislative or jurisprudential recognition of personality rights, English courts are increasingly stretching the boundaries of existing rights to strike a balance between competing interests and to recognise the commercial value of image rights. ${ }^{8}$ This has become a challenging task, particularly in the new technological era where images, photos and knowledge can be shared worldwide instantaneously and anonymously.

\subsection{Passing off}

Even though English judges do not expressly recognise a general personality or image right per se, the common law action passing off has always been a flexible instrument to take into account new developments including false endorsement and false merchandising claims.

In this context, the scope of an action of passing off was tested in the recent decision of the English Court of Appeal concerning the protection of image rights, involving the famous pop star Rihanna and the fashion chain Topshop. ${ }^{9}$

The Court of Appeal confirmed the basic principle that in English law there is no "image right" or "character right" which allows a celebrity to control the use of his or her name or image. ${ }^{10}$ The court upheld the trial judge's finding ${ }^{11}$ that Topshop's unauthorised use of Rihanna's image on a T-shirt was passing off.

5 Proactive Sports Management Ltd v Rooney \& Ors [2011] EWCA Civ 1444 para 1 per Lady Justice Arden.

6 Von Hannover v Germany (No 2) (App nos 40660/08 and 60641/08 [2012] EMCR 16 (ECtHR, Grand chamber), para 96.

7 Romer, Storey (2013) 51; Middlemiss, Warner (2006) 131-142.

8 Cornish, Llewelyn (2003) 618.; Walsh (2013) 253-260.

9 Fenty \& Ors v Arcadia Group Brands Ltd \& Anor [2015] EWCA Civ 3.

10 Fenty \& Ors v Arcadia Group Brands Ltd \& Anor, per Lord Justice Kitchin, para 29.

11 Fenty \& Ors v Arcadia Group Brands Ltd (t/a Topshop) \& Anor [2013] EWHC 2310 (Ch). 
The facts of the case were that in March 2012 Topshop, a well-known fashion retailer, started selling a T-shirt with an image of Rihanna on it. The image in question was of Rihanna during a video-shoot for her 2011 "Talk That Talk" album. Topshop had obtained a licence from the photographer but no licence from Rihanna. Rihanna claimed that the sale of this T-shirt without her permission infringed her rights and brought an action against Topshop for passing off and trade mark infringement.

Since Reckitt \& Colman Ltd v Borden Inc ${ }^{12}$ in 1990 - also known as the Jif Lemon case - in order to succeed in a passing off action the claimant has to prove that: (1) he/she possesses a reputation or goodwill in his/her goods, name or mark; (2) there has been a misrepresentation by the defendant which has led to confusion; (3) this misrepresentation has caused damage to the claimant's reputation or goodwill in the claimant's goods, name, mark.

The High Court found that all of these elements were present in the Rihanna case, arguing that the retailer was taking advantage of "Rihanna's public position as a style icon"13 to increase its own sales. Moreover, the Court found that the use of that particular image on the T-shirt might lead Rihanna fans to believe that it was part of her marketing campaign for the album. ${ }^{14}$ Mr Justice Birss concluded, "Many will buy a product because they think she (Rihanna) has approved of it. Others will wish to buy it because of the value of the perceived authorisation itself. In both cases they will have been deceived." 15

The fact that Rihanna already has her own clothing line with Topshop rival River Island and enjoyed substantial goodwill in the UK and the position of Topshop as a major reputable high street retailer were crucial to a finding of passing off.

One of the first false endorsement cases in the UK before this was Irvine v Talksport in 2003 where the radio station Talksport had sent out promotional material to potential advertising buyers including a brochure featuring a photograph of the F1 racing driver Eddie Irvine. ${ }^{16}$ In this case Talksport had manipulated a previous photo of Irvine in which he had been holding a mobile phone by superimposing the Talksport radio onto the image in place of the phone. Irvine successfully sued Talksport Radio for passing off.

The Irvine case was of particular importance for the development of image right protection in the UK, bringing traditional passing off law up to date with modern commercial reality. If the actions of the defendant created a false message which would be understood by the customers to mean that his goods have been endorsed or recommended by the claimant, then the claimant can succeed in passing off. ${ }^{17}$

Considering the special circumstances in the Rihanna case, it is not surprising that the Court of Appeal confirmed the decision of the trial judge and found in her favour. The classic passing off elements and circumstances leading to false endorsement as in Irvine $\mathrm{v}$ Talksport were present. The T-shirt damaged Rihanna's goodwill, would result in loss of sales for her own merchandising business if a substantial number of consumers were likely to buy the T-shirt falsely believing that it was authorised by Rihanna and represented a loss of control over her reputation in the fashion sphere.

12 Reckitt \& Colman Products Ltd v. Borden Inc [1990] RPC 341.

13 Fenty \& Ors v Arcadia Group Brands Ltd \& Anor [2015] EWCA Civ 3., para 45.

14 Fenty \& Ors v Arcadia Group Brands Ltd \& Anor [2015] EWCA Civ 3. para 69.

15 Fenty \& Ors v Arcadia Group Brands Ltd \& Anor [2015] EWCA Civ 3, para 72.

16 Irvine v Talksport [2002] 2 All ER 414 (Laddie J), [2003] EWCA Civ 423.

17 Irvine v Talksport [2002] 2 All ER 414 (Laddie J), [2003] EWCA Civ 423., para 25. 
The decision of the Court of Appeal, however, is unlikely to open the floodgates for claims to be brought every time a celebrity image is used without a licence on merchandising. The trial judge, Mr Judge Birss, had already emphasised that "Whatever may be the position elsewhere in the world, and however much various celebrities may wish there were, there is today in England no such thing as a free standing image right". ${ }^{18}$

It follows that each case will depend on the individual circumstances, in Rihanna's case, her past association with Topshop and the particular features of the image itself, and that, "the mere sale by a trader of a T-shirt bearing an image of a famous person is not, without more, an act of passing off." 19

\subsection{Trademark Protection}

In addition to the tort of passing off, the registration of a trademark may provide effective protection against the unauthorised commercial exploitation of the image of a celebrity. Generally, the successful registration of a famous name or image as a trade mark prevents a third-party from using the trade mark in the course of their own trading. One of the advantages of a registered trade mark is that it is easier to enforce because it automatically enjoys protection in the jurisdiction within which it is registered, while the claimant in a cause of action for passing off has to prove the three essential elements: goodwill, misrepresentation and damage. The registration of celebrities as such, however, has proved difficult and has been put into question since the appeal in Elvis Presley Enterprises Inc v Sid Shaw Elvisly Yours. ${ }^{20}$ In this case the Court of Appeal upheld the decision to overturn registration of a variety of styles of the name Elvis Presley. The court decided that a celebrity name was not registrable as a trade mark as it was not distinctive. The court appeared to acknowledge the monopoly power that could be conferred on traders if celebrities' names could be registered as trademarks. Simon Brow LJ noted: "there should be no a priori assumption that only a celebrity or his successors may ever market (or licence the marketing of) his own character. Monopolies should not be so readily created". ${ }^{21}$

Although this case was considered under the old Trade Marks Act 1938, the principles in the case are still relevant to the consideration of modern trademark applications and has been followed in the decision by the trademark registry to turn down the application to register the name "Diana, Princess of Wales" as a trademark. ${ }^{22}$

The Princess of Wales sought registration of the words DIANA, PRINCESS OF WALES in a very wide range of goods and services. The application was based on the view that there was a significant trade in DIANA, PRINCESS OF WALES souvenirs whilst the late Princess of Wales was alive, and a trade in memorabilia in the immediate aftermath of her death.

18 Fenty \& Ors v Arcadia Group Brands Ltd \& Anor [2015] EWCA Civ 3, para 2.

19 Fenty \& Ors v Arcadia Group Brands Ltd \& Anor [2015] EWCA Civ 3, para 75. See also: Fletcher, Mitchell (2015) 405.

${ }^{20}$ Elvis Presley Enterprises Inc v Sid Shaw Elvisly yours [1999] RPC 567. Waelde, Laurie (2014) 817.

21 Waelde, Laurie (2014) 598. See also Lord Parker of Waddington in Registrar of Trade Marks v W. and G. Du Cros Ltd. (1913) AC 624 at 634, 635: "It is apparent from the history of trade marks in this country that both the Legislature and the Courts have always shown a natural disinclination to allow any person to obtain by registration under the Trade Marks Acts a monopoly in what others may legitimately desire to use."

22 Executrices of the Estate of Diana, Princess of Wales' Application [2001] ETMR 25. 
The application was rejected on the basis that it was unlikely the public would attach any trade mark significance to the Princess's name appearing on commemorative products given there was no such significance when she was alive. The average and circumspect consumer would not expect that all commemorative articles bearing the Princess's name were commercialised under the control of a single undertaking. The application was also rejected because the name lacked the necessary trademark character for the goods listed in the application.

Similarly, an application to register the name "Jane Austen" in respect of toiletries and similar goods was rejected. ${ }^{23}$ It was successfully argued that the mark was devoid of distinctive character under section 3(1)-(b) of the Trade marks Act 1994.

These cases show that for a famous name to qualify for a trademark registration the public must associate the celebrity with the goods sought for registration. The public association will ensure that the celebrity's name will be seen to be indicating origin and will not merely be indicating subject matter. ${ }^{24}$ It follows that the celebrity should seek to educate consumers to view its trademark as a source identifier as opposed to a common name for its goods and/or services, as otherwise, it is unlikely that the celebrity's name will be considered a designation of origin.

\subsection{The developing Law of Privacy}

Although historically, English common law has recognised no general tort of privacy, privacy in English law is a rapidly developing area that considers in what situations an individual has a legal right to informational privacy - the protection of personal or private information from misuse or unauthorised disclosure. ${ }^{25}$ In the absence of a tort of privacy, the equitable remedy of breach of confidence, a variety of torts limited to intentional infliction of harm to the person and administrative law principles relating to the appropriate use of police powers have all been recently used to resolve cases which involve allegations of an infringement of personal privacy. In relation to the law of breach of confidence in Prince Albert v Strange, for example, the High Court of Chancery awarded Prince Albert an injunction, restraining Strange from publishing a catalogue describing Prince Albert's etchings. ${ }^{26}$ In Coco v AN Clark (Engineers) Ltd $^{27}$ a claim was made for breach of confidence in respect of technical information whose value was commercial. In this case the information was found not to be of a confidential nature as it was already in the public domain.

In Kaye v Robertson the claimant, a well-known actor, attempted to obtain an order restraining the publication of photographs of the injuries he had sustained in a car crash which had been obtained via deception by a tabloid's journalist while he was still in hospital undergoing treatment. ${ }^{28}$ The claimant argued that he was entitled to relief based on a multitude of different torts, including libel, trespass and nuisance.

The Court of Appeal concluded that only malicious falsehood was applicable to the circumstances of the case having decided that no tort of privacy existed in English law with

23 Jane Austen Trade Mark [2000] RPC 879.

24 Beverly-Smith (2004) 41; see Linkin Park LLC [2006] ETMR 74.

25 Bainbridge (2012) 347.

26 Prince Albert v Strange [1849] EWHC Ch J20.

27 Coco v AN Clark (Engineers) Ltd [1969] RPC 41.

28 Kaye v Robertson [1991] FSR 62. 
the House of Lords in Wainwright v Home Office confirming this view. ${ }^{29}$ Privacy rights have, however, received increasing recognition both nationally and at European level. The key justification for this change is Art. 8 (1) of the European Convention on Human Rights (ECHR) which provides a right to respect for a person's private and family life. Two recent cases reflect the fast developing area of privacy law in the UK which has been supported and enhanced by the enactment of the Human Rights Act 1998.

\section{Douglas v Hello}

The first case concerned the two actors, Michael Douglas and Catherine Zeta-Jones. The stars had married in November 2000 and had granted exclusive rights to pictures of their wedding to the Ok! magazine but the defendant, the publisher of the Hello! magazine had its own pictures, which it planned to publish. On application the claimants obtained an interim injunction in the High Court, preventing the defendant from publishing unauthorised photographs of the claimants' wedding on the grounds that the pictures were a breach of confidence and an invasion of the individual claimants' privacy. The defendant, Hello! magazine, successfully appealed to the Court of Appeal, which discharged the interim injunction against the defendant. An emergency injunction was granted which was set aside three days later by the Court of Appeal and the images were later published in Hello!.

The Douglases succeeded in this case because the wedding and party were held to be private events, on private property. The House of Lords affirmed the claimants' right to hold their wedding in private and protect their intimate moments from the distressing and invasive effects of unauthorised photography. The House of Lords, by a split majority of $3-2$, upheld the action for breach of confidence. The main issue was whether the photographs represented confidential information. The majority ruled that the disputed photographs provided information as to how the wedding looked and constituted confidential information.

However, Lord Walker in Douglas v Hello summed up his position on image rights as follows: "under English law it is not possible for a celebrity to claim a monopoly in his or her image as if it were a trademark or a brand". 30

Moreover, Lord Justice Hoffman noted: "there is (...) no question of creating an 'image right' or any other unorthodox form of intellectual property. The information in this case was capable of being protected (...) simply because it was information of commercial value over which the Douglases had sufficient control to enable them to impose an obligation of confidence". 31

\section{Campbell v Mirror Group Newspapers}

In Naomi Campbell v Mirror Group Newspapers the model Naomi Campbell was photographed leaving a rehabilitation clinic where she attended regularly meetings of Narcotics Anonymous ("NA"). ${ }^{32}$ The photographs were published in a publication run by MG Newspapers. The headline alongside the photograph read: "Naomi: I'm a drug addict" and the article contained some general information relating to Miss Campbell's treatment

29 Wainwright $v$ Home Office [2003] UKHL 53.

30 Douglas $v$ Hello [2007] UKHL 21, para 293 per Lord Walker.

31 Douglas $v$ Hello [2007] UKHL 21, para 124 per Lord Hoffmann.

32 Campbell v MGN Ltd [2004] UKHL 22 on appeal from Campbell v MGN Ltd [2002] EWCA Civ 1373. 
for drug addiction, including the number of meetings she had attended in the clinic. The supermodel had previously claimed that she did not have a drug addiction. Miss Campbell claimed damages under the tort of breach of confidence. On appeal, the House of Lords, by a 3:2 majority, held that this was a breach of confidence. Whilst it was acceptable to publish a story about her having lied about taking drugs and her addiction and the fact that she was receiving therapy, publishing the additional information about the treatment with NA together with details of the treatment and photograph went too far and were not relevant for the public discourse. ${ }^{33}$

However, in her judgment Baroness Hale of Richmond made clear that: "in this country we do not recognise a right to one's own image. (...) We have not so far held that the mere fact of covert photography is sufficient to make the information contained in the photograph confidential. ${ }^{34}$

In summary, to obtain protection under English privacy laws the activity photographed must be private. If by contrast, someone published a picture of a celebrity going shopping in a public street, a claim for breach of confidence or privacy would most likely fail. Children may enjoy special protection as held in Murray v Express Newspaper Plc where a photographer depicted the author JK Rowling's son David, then 19 months old, being pushed in a buggy with his parents in an Edinburgh street to and from a local café. In that case it was arguable that an expedition to the café was part of each member of the family's recreation time, such that publicity was intrusive and likely to adversely affect such activities in the future. ${ }^{35}$ The recent case Mosley v News Group Newspapers also shows that courts have been more willing to rule that adulterous or casual sex affairs are matters in which one or both of the people involved have a reasonable expectation of privacy and will issue injunctions unless the defendant can persuade the judge there is a strong public interest in publishing the information. ${ }^{36}$ The facts of the case were that Max Mosley, the former president of the Fédération Internationale de l'Automobile (FIA), was awarded $£ 60,000$ against the News of the World in an action alleging breach of confidence and unauthorised disclosure of personal information for its exposure of his participation in a sado-masochistic orgy with prostitutes.

The English law on privacy has therefore strengthened the economic and private rights of celebrities but it is questionable if and when ordinary people have a right to commercial confidence. What the cases show is that even celebrities have a right of privacy during private events on private property and with regard to information about a person's health and their treatment for ill health. Moreover, Campbell has established that the values enshrined in Art. 8 and 10 ECHR will now be considered as part of a cause for an action of breach of confidence.

33 Campbell v MGN Ltd [2004] UKHL 22 on appeal from Campbell v MGN Ltd [2002] EWCA Civ 1373., para 24 per Lord Nicholls of Birkenhead.

34 Campbell v MGN Ltd [2004] UKHL 22 on appeal from Campbell v MGN Ltd [2002] EWCA Civ 1373., para 154, per Baroness Hale of Richmond.

35 Murray v Express Newspapers Plc [2008] EWCA Civ 446 and recently in: Weller v Associated Newspapers Ltd [2014] EWHC 1163 (QB).

${ }^{36}$ Mosley v News Group Newspapers [2008] EWHC 1777 (QB); see also Mosley v United Kingdom [2011] 53 E.H.R.R. 30. 


\section{IMAGE RIGHTS IN HUNGARY}

\subsection{Definition of the Term "Image Right" in Hungary}

Image rights under Hungarian law form part of a much broader concept of personality rights. These rights have their roots both in Hungarian constitutional law and civil law. ${ }^{37}$ Although personality rights per se are not listed among the fundamental rights of Hungarians under the current Fundamental Law, ${ }^{38}$ some of the fundamental rights have inherent connection with the personality of human beings. ${ }^{39}$ The legal literature correctly points out, however, that the basic purpose of the Fundamental Law is to list the fundamental rights and principles that a democratic country shall respect and enforce. The content of these rights - including personality and image rights - might be regulated by separate laws, ${ }^{40}$ so for example by the Civil Code of Hungary. ${ }^{41}$

The Hungarian civil law was amended by the acceptance of the Hungarian Civil Code (HCC) in 2013. HCC 2013 replaced HCC 1959 on March 15, 2014. In HCC 1959 image rights were listed under Title IV on "civil law protection of persons" and Chapter VII on "personality and intellectual property rights". ${ }^{42}$ Currently, image rights are included within Book II on "Persons", Part III on "Personality Rights" and Title XI on "General clauses and certain personality rights". 43

Personality rights, generally, provide for a right of protection against different forms of intrusion into the private sphere of persons. The structure of the rules on personality rights is absolute, that is, they are based on prohibitions and everyone is obliged to respect such rights. Any behaviour to the contrary might lead to an enforceable infringement. Personality rights are therefore closely connected to the integrity of different aspects of a person's life and privacy.

Personality rights are limited under the HCC 2013. Infringements are excluded, where the affected person directly or indirectly approved the behaviour of the user ("volenti non fit injuria"), ${ }^{44}$ or where the law allows for such intrusion (for example in order to use images for evidence purposes in criminal trials). ${ }^{45}$ All the above aspects show that Hungarian civil law does not focus on the exploitation (economic) aspects of personality and image rights.

The wording of the rules on image rights under HCC 1959 and HCC 2013 show some significant differences. The old regime generally prohibited any misuse of the image (visual depiction) of a person (that is, his or her likeness) or the audio and/or video recording of

37 On the historical and doctrinal analysis of personality rights under the Hungarian Civil Code of 1959 (Act IV of 1959, hereinafter: HCC 1959) see: Sólyom (1983). On the most recent systematic analysis of image rights see: Boronkay (2014). I-XXXI.

38 Magyarország Alaptörvénye (2011. április 25.), Chapter “Szabadság és Felelösség”, Arts.

39 E.g. freedom and personal safety [Art. IV(1)]; fair trial provisions [Art. IV(2)-(4); defence against unlawful attack on the person [Art. V]; protection of private and family life, home, goodwill or personal data [Art. VI]; freedom of expression [Art. IX] and so forth.

40 Petrik (2013) 145.

41 See further: A személyhez füződő jogok (2005) 3.

42 "A személyek polgári jogi védelme" and "A személyhez és a szellemi alkotásokhoz füzödo" jogok", respectively. See: HCC 1959, Art. 80.

43 "Az ember mint jogalany", "Személyiségi jogok" and "Általános szabályok és egyes személyiségi jogok”, respectively. See: HCC 2013, Art. 2:48.

44 Boronkay (2014) 17-19.

45 Petrik (2013) 147-148.; A személyhez füződő jogok (2005) 4. 
a person's voice, or the mixture of these two. ${ }^{46}$ HCC 1959 specifically required the affected person to authorise exposure of the image or recording to the public. ${ }^{47}$ Case law under HCC 1959 confirmed that the unauthorized recording of someone's voice is per se an infringement, and consequently the user had to rely on a defence to avoid liability. ${ }^{48}$ Furthermore, the use of a picture of a person required permission with respect to both the creation of the photograph and the method of use. ${ }^{49}$ Alternatively, courts have consistently refused to treat the verbal and written disclosure of the substance of a sound recording, as well as the conveyance of the existence of a sound recording and a photograph as an intrusion to the image rights of persons. ${ }^{50}$

HCC 1959 explicitly allowed for the use of images and recordings of missing persons or people who were subject to criminal proceedings for committing serious crimes given that "weighty public interests" (especially the discovery of the crimes) or "equitable private interests" support such disclosure. ${ }^{51}$ Case law confirmed the legality of the use of images, ${ }^{52}$ video recordings ${ }^{53}$ and sound recordings ${ }^{54}$ both in criminal and - somehow expanding the scope of the provision - in petty offence procedures for purposes of evidencing. ${ }^{55}$

Furthermore, public figures (especially politicians) had to tolerate broader (harsher) expressions/opinions of people, especially due to the fact that they were fulfilling their duties in favour of society. So for example image rights of politicians were not infringed where photographs functioning as a caricature were published about them as long as such opinion of the publisher fits within the general frames of freedom of expression. ${ }^{56}$ Alternatively, images of public figures might be only used with regards to their public acting/performance. ${ }^{57}$

In a notable case - decided under the rules of the HCC 1959 - the Court of Appeal of Budapest decided that photographing policemen in service infringes the personality rights of the policemen. ${ }^{58}$ Later, however, the decision was found unconstitutional, and the Hungarian Constitutional Court overruled the judgment, claiming that any photograph that was taken at a public place and serves the interest of news reporting shall be disclosed without authorisation of the depicted persons. ${ }^{59}$ In its decision the Constitutional Court opined that when the different rights and interests of policemen and that of the whole society clash, the latter shall prevail. The Constitutional Court highlighted that freedom of

46 HCC 1959, Art. 80 para (1). Compare to: A személyhez füződő jogok (2005) 9.

47 HCC 1959, Art. 80 para (2).

48 BH 2008/266.

49 BH+ 2015/13. Compare to: A személyhez füződő jogok (2005) 10.

50 EBH 2012.P.16; BH+ 2013/155.

51 HCC 1959, Art. 80 para (2).

$52 \mathrm{BH}+2011 / 199 ; \mathrm{BH}+2015 / 13$.

53 EH 2000/296.

${ }^{54} \mathrm{BH}+2013 / 324$.

55 Compare to Boronkay (2014) 24-25.

56 BH 1994/127; BH 2000/293. See further: Halmai (2000) 17-32.

57 BH 2006/282. See further: Boronkay (2014) 23. Under BDT2006.1298 public acting means any performance in events that might affect the life of the society; that might influence the national or local issues; or that were organized with such purposes.

58 Fövárosi Ítélótábla Pf.20.656/2012/7. The decision was later approved by the Curia (Supreme Court) as well. See: BH 2014/104. Note that the latter decision was handed down before the ruling of the Hungarian Constitutional Court that ultimately quashed the Court of Appeals' decision.

59 28/2014. (IX. 29.) AB határozat. 
press has been a part of the Hungarian historical constitution. ${ }^{60}$ It functions as the means to create and maintain democratic public opinion, and all forms of press shall be equally protected under this fundamental right. ${ }^{61}$ Further, the distinct treatment of the right to privacy and the recording of the likeness or the voice of a person in public places is in accordance with the ECHR and the practice of the ECtHR. ${ }^{62}$ Consequently, the Constitutional Court has based its final decision on the constitutional aspects of freedom of press and human dignity, rather than civil law. ${ }^{63}$ As such, the protection of personality rights needs to be balanced with the freedom of press, as well as the right to receive and impart information in cases of public interest. ${ }^{64}$ The Constitutional Court declared the reporting of public events (assemblage of members of the union of protective services) a direct realisation of freedom of press and the freedom to impart information, as well as the shaping of "democratic public opinion". ${ }^{65}$ With respect to the issue at hand, the majority opinion of the decision noted that reporting of the assemblage shall not be limited under personality rights, as long as imparting information on the event is not abusive. ${ }^{66}$ As such, taking photographs of policemen serving at (securing the safety of) a current assemblage deserves public attention, even if policemen are not "real participants" of the event. Exceptions to the freedom to record the likeness of policemen might exist. Such an example is where the human dignity is infringed by the reporting (like depicting the suffering of injured policemen), or where only one policeman is recorded on the image. ${ }^{67}$ Consequently, a factual, objective visualization of the crowd of a public event shall be treated as lawful and necessary in order to depart information by the press. ${ }^{68}$ Ultimately the Constitutional Court quashed the Appeals Court decision that decided the case in the opposite way. ${ }^{69}$

The new wording of image rights under HCC 2013 builds upon the regulations of HCC 1959, but - at the same time - codifies the case law introduced above. The current law requires the authorization of the affected persons to the creation as well as any form of use of an image or recording, ${ }^{70}$ including but not limited to reproduction, distribution, performance, display, transmission or making available (via the internet) to the public. ${ }^{71}$

No infringement occurs, where the affected person authorised the use of the image or recording either directly or indirectly. No authorisation is needed, however, where the picture or recording is taken of a crowd ("tömegfelvétel") 72 or of a "performance at a public event" ("nyilvános közéleti szereplés"). The latter limitation requires some clarification. The definition of "performance at a public event" is broader than the concept of performances of public figures. ${ }^{73}$ HCC 2013 clearly allows for the unauthorized photographing of and

60 28/2014. (IX. 29.) AB határozat, paras. [11]-[14].

61 28/2014. (IX. 29.) AB határozat, paras. [15]-[17].

62 28/2014. (IX. 29.) AB határozat, paras. [25]-[26].

63 28/2014. (IX. 29.) AB határozat, para. [27].

64 28/2014. (IX. 29.) AB határozat, para. [35].

65 28/2014. (IX. 29.) AB határozat, para. [38].

66 28/2014. (IX. 29.) AB határozat, para. [42].

67 28/2014. (IX. 29.) AB határozat, paras. [43-44].

68 28/2014. (IX. 29.) AB határozat, para. [48].

69 28/2014. (IX. 29.) AB határozat, para. [49].

${ }^{70}$ HCC 2013 Art. 2:48 para. (1)

71 Petrik (2013) 157.

72 Compare to: A személyhez füződő jogok (2005) 10.

73 On the concept of public figures see: Törő (1979) 22.; Sarkady (2006). 
recording the voice of celebrities as well and not only "politically exposed persons", as long as the affected performance is a part of "public life", that is, it exceeds the limits of the performer's private life and it deserves attention from the publicity. Furthermore, the limitation of personality rights of "politically exposed persons" is explicitly allowed by HCC 2013. It stresses that "exercising the fundamental rights relating to the free debate of public affairs may diminish the protection of the personality rights of politically exposed persons, to the extent necessary and proportionate, without prejudice to human dignity". ${ }^{74}$ Such regulation a contrario confirms that the personality rights of celebrities deserve stronger protection. Notwithstanding the above, the private life of persons - following the standards of international human rights documents - is protected by the HCC 2013 as a separate personality right. $^{75}$ Any arbitrary - unreasoned or statutorily not permitted intrusion into the privacy of persons, including "politically exposed persons" and celebrities as well, shall be prohibited. ${ }^{76}$ Notwithstanding the above, Menyhárd recently opined that such separate protection of the private life of people under civil law might be unnecessary. First, such interest is protected as a fundamental right under international and domestic norms, and these laws include obligations of the countries/governments to defend their nationals' rights. Second, the privacy of people is specifically protected through multiple unique rights - both under the Constitution and/or the HCC. ${ }^{77}$ It is consequently necessary to differentiate between the general right of personal right and the other specific rights of privacy. It is the task of the courts to meet this challenge. ${ }^{78}$

\subsection{Intellectual Property Rights}

As HCC 2013 functions as lex generalis for all civil matters, it necessarily evades answering specific questions that might arise under lex specialis provisions, for example under intellectual property rights. Both copyright law and trademark law include rules that are closely connected to the protection of private interests over the images of and recordings of the voice of persons. The lex specialis nature of these statutes means, however, that not the person or the personality rights are protected, but rather the expressions of these persons, as long as these expressions fit into the relevant subject matter of the copyright or trademark laws.

The Copyright Code of Hungary rules on the protection of works of authorship and other protected achievements (performances, recordings, broadcasts etc.). Not the ideas or the forms, but the expressions that are original in nature are protected. As such an image that visually depicts a person might be automatically ${ }^{79}$ protected as a protected subject matter (as a photographic work). ${ }^{80}$ Copyright is, however, solely granted to the photographer,

74 HCC 2013 Art. 2:44.

75 HCC 2013 Art. 2:43 point b).

76 See especially Supreme Court's decision no. Pfv.IV.21.028/2000 from the case law under HCC 1959. The decision seems to be fully applicable under the current rules of HCC 2013.

77 See for example: life or health of people, protection of integrity and personal data, protection against discrimination, defamation or trespassing.

78 Menyhárd (2014) 178.

79 Compare with the Painer decision of the Court of Justice: Eva-Maria Painer v Standard Verlags GmbH and Others, Case C-145/10, ECLI:EU:C:2013:138.

${ }^{80}$ Act LXXVI of 1999, Art. 1 para. 2 point i). The latest version of the statute that is available via WIPO's database (http://www.wipo.int/wipolex/en/details.jsp?id=11840) is valid in respect of the quoted paragraphs. 
that is, the author of the work, since the likeness of a person (his face or fully body image) does not function as an expression, but rather as a mere fact. In Hungary, printing the face of the famous Italian actor, Bud Spencer, is quite common, as well as selling products with the tag of "beer and sausage competition" that refers to a remarkable scene of the movie “...altrimenti ci arrabbiamo!” (“Különben dühbe jövünk”, "Watch Out, We're Mad!”, 1974). In the movie Bud Spencer and Terence Hill competed in drinking beer and eating sausages until losing consciousness. This type of competition became a form of amusement amongst college students in Hungary.

Audio or video recordings of the voice of persons are treated in a more complex fashion under copyright law. Publicly held speeches are protected subject matter, ${ }^{81}$ and consequently the author of the speech deserves copyright protection. Although the Berne Convention might allow for the opposite, ${ }^{82}$ the Copyright Code of 1999 did not exclude public speeches held by politicians from the scope of protected subject matters. Furthermore, performers and producers of the audio and video recordings similarly deserve neighbouring rights protection. In the latter cases, no originality is necessary on the side of the producer and the performer in order to be covered by the rules of the Copyright Code. Still, the HCC, as lex generalis, comes into the foreground. As we have stressed above, under Art. 2:48 para. (2) no authorization is needed to make a voice recording taken of a crowd or of a "performance at a public event". Consequently, any other recording might be subject to authorisation. So for example a public university lecture shall not be classified as a performance in the crowd ("tömegfelvétel") or at a public event (here, again, the Hungarian expression is more descriptive: "nyilvános közéleti szereplés").

Finally, the Copyright Code of 1999 also includes provisions on merchandising rights; however, these are all attached to original works of expressions, especially unique and original characters or the title of a work ${ }^{83}$ rather than the likeness or voice of a person, even if the latter is the author of such titles or characters.

The Hungarian Trademark Law grants protection to "any signs capable of being represented graphically provided that these are capable of distinguishing goods or services from those of other undertakings". ${ }^{84}$ These signs might include names, pictures and sound signals as well. ${ }^{85}$ The use of names as trademarks is quite common in Hungary as well; ${ }^{86}$ however, no widely known example might be presented, where the name of a person that was not closely connected to goods or services and that does not have any unique, distinctive feature was registered. Similarly, the likeness or the recorded voice of a person might function as a trademark, if it is distinctive and is capable of incorporating the respected good or service. A notable example of trademarked slogans of celebrities is the one that the late sport reporter, Jenö Knézy used. He would start his commentary at all sports events

${ }^{81}$ Act LXXVI of 1999, Art. 1 para. 2 point b).

82 Compare to the Berne Union Convention (1971), Art $2^{\text {bis }}$ para 1.

83 Act LXXVI of 1999, Art. 16 paras. 2-3.

${ }^{84}$ Act XI of 1997, Art. 1 para. 1. The English translation of the statute is available via WIPO's database: http://www.wipo.int/wipolex/en/text.jsp?file_id=330915. On the substantive requirement of distinctiveness see: Vida (2010) 75-78.; Szalai (2010) 8-33.

85 Act XI of 1997, Art. 1 para. 2 points a), c) and f). Here, the protection of sound signals - that are not graphical, but aerial signs - under Art. 1 para 2 point f) necessarily broadens the scope of Art. 1 para. 1 that explicitly refers to signs that might be graphically represented.

86 See for example: László, Mező (2013) 26-30. 
with "good evening and enjoy the game" ("jó estét, jó szurkolást"). ${ }^{87}$ Another example is that of the likeness of the former reality show celebrity Alekosz which was depicted in his unique pose, where the ultimate picture was used as the advertisement for another reality show titled "Love Supreme - Alekosz is looking for a wife" ("Szerelem a legfelsöbb szinteken - Alekosz feleséget keres"). ${ }^{88}$ The above examples are clearly connected to commercially exploitable services, and they evidence that the mere name, likeness and voice of a person cannot be protected under trademark law without such direct distinctiveness.

\section{COMPARATIVE AND CONCLUDING REMARKS}

A comparison of the legal systems of the UK and Hungary indicates several major differences with respect to image rights. ${ }^{89} \mathrm{~A}$ fundamental reason for that diversity comes from the traditional distinguishing of common law and statute law. Hungarian civil law fully recognises a right of personality and provides explicit statutory protection against the unlawful commercial exploitation of an individual's image. In contrast, English judges still do not expressly recognise a general image right, however, the common law actions of passing off and breach of confidence have always been useful instruments to flexibly adapt to developments including false endorsement and false merchandising claims. In addition to the explicit statutory protection provided in Hungary, both systems provide for protection under specific intellectual property laws, in particular trade mark law or copyright law. As we have seen, however, the prerequisites of the use of images and recorded voice under the rules of copyright and trademark law are quite special, and therefore the scope of such exploitation is quite tight.

To qualify for trademark registration in cases where the celebrity is already famous, the public must associate the celebrity with the goods sought for registration and the name or likeness must be sufficiently distinctive. Copyright under both systems is more likely to assist in protecting the rights of the broadcaster or photographer but situations rarely arise where copyright provides a realistic means of protecting a person's image as such. In the UK, however, in addition to that, copyright may subsist in the image of fictional characters, providing a cause of action against its unauthorised use by third parties, alongside other heads of claim, such as passing off.

Although historically, English common law has recognised no general tort of privacy, privacy in English law is a rapidly developing area that considers in what situations an individual has a legal right to informational privacy - the protection of personal or private information from misuse or unauthorised disclosure. Where there is reasonable expectation

87 Application number: M9803164; registration number: 157778. The application for the trademark was submitted by Knézy's children, Jenö Knézy, Jr. (who is a sport reporter as well) and Beatrix Knézy. The trademark application was submitted on August 5, 1998, and it was registered on September 14, 1999. Knézy passed away in 2003, and the protection was not renewed in 2008.

${ }^{88}$ Application number: M1101262; registration number: 204548. The application for the trademark was submitted by Magyar RTL Televízió Zrt., the owner of Hungary's most popular television channel (RTL-Klub). The trademark application was submitted on April 21, 2011, and it was registered on October 26, 2011.

89 On the differences between the British and Hungarian - and several other - legal systems with respect to privacy see: Menyhárd (2014) 180-201. 
of privacy, taking and publishing of photographs without consent is likely to be an invasion of privacy, unless there is a clear public interest at stake. The law on privacy has partially changed in the last few years in Hungary. The new HCC has - at least partially - codified the former case law on this issue; however, it left unanswered several significant questions. Menyhárd correctly noted that the boundaries between private interests of people (especially those under "private life" and any other rights under HCC) still need to be settled by the judges. As a matter of fact, such new regulations do not seem to be in any contradiction with the special laws on intellectual property law. Consequently, HCC 2013 and the copyright and trademark laws may easily complement each other: HCC 2013 rules on the existence of the rights and interests of persons; whilst Intellectual Property norms regulate the economic exercise of privacy rights.

In the absence of a formal legislative or jurisprudential recognition of image rights and what has been identified as "piecemeal" legislation and protection, English courts are increasingly stretching the boundaries of existing rights to strike a balance between competing interests and to recognise the commercial value of image rights. It remains to be seen whether English Courts will gradually recognise the existence of a proper personality or image right in the near future. Unlike their British colleagues, Hungarian judges do not need to significantly change the practice on image rights. This is especially true in light of the decision of the Constitutional Court on the publication of photographs of policemen. Although that decision has left a certain margin of discretion for judges to consider the facts of the cases on an individual basis (especially with respect to the private life of public figures), it has confirmed that a factual, objective visualisation of the crowd of a public event should be treated as lawful and necessary in order to obtain and make information available by the press.

It follows that the protection afforded to images by Hungarian Law is broader than in the UK, and generally sufficient to protect a personality against the use of images for commercial purposes.

\section{LITERATURE}

Bainbridge, D., Intellectual Property, (9 ${ }^{\text {th }}$ ed, Pearson 2012).

Beverly-Smith, H., The commercial appropriation of personality (Cambridge University Press 2004).

Blum, J., Ohta, T., 'Personality disorder: strategies for protecting celebrity names and images in the UK' (2014) 2 Journal of Intellectual Property Law \& Practice 137-147.

Boronkay, M., 'A képmáshoz és a hangfelvételhez füződő jog' in Z Csehi and A Koltay and Z Navratyil, A személyiség és a media a polgári és a büntetőjogban az új Polgári Törvénykönyvre és az új Büntetö Törvénykönyvre tekintettel (Wolters Kluwer 2014) 11-56.

Cornish, W., Llewelyn, D., Intellectual Property: patents, copyright, trademarks and allied rights $\left(5^{\text {th }}\right.$ ed, Sweet and Maxwell 2003).

Fletcher, S., Mitchell, J., 'Court of Appeal found no love for Topshop tank: the image right that dare no speak its name' (2015) 1 European Intellectual Property Review 394-405.

Halmai, G., 'Közszereplők személyiségvédelme kontra közügyek vitathatósága', (2002) 2 Fundamentum 17-32.

László, Á. M., Mező, B., 'Kell a cégér! A forgalmazói védjegyhasználat egyes kérdései’, (2013) 2 Iparjogvédelmi és Szerzői Jogi Szemle 26-30.

Menyhárd, A., 'A magánélethez való jog a szólás- és médiaszabadság tükrében' in Z Csehi and A Koltay and Z Navratyil, A személyiség és a média a polgári és a büntetöjogban az új Polgári Törvénykönyvre és az új Büntetö Törvénykönyvre tekintettel (Wolters Kluwer 2014) 177-226.

Petrik, F., 'Személyiségi jogok' in L Kecskés and A Körös and K Makai and Á Orosz and A Osztovits and F Petrik, Az új Ptk. magyarázata I/VI. - Polgári Jog, Bevezető és záró rendelkezések, az ember mint jogalany, öröklési jog (HVG-Orac, 2013) 166-214. 
I. Könyv: A személyek - III. Rész: A személyhez füződő jogok, (2005) 3 Polgári Jogi Kodifikáció $3-15$.

Romer, J., Storey, K., 'Image is everything! Guernsey registered image rights', (2013) 1 Entertainment Law Review 51-56.

Sarkady, I., 'A közszereplök személyiségvédelme a bírói gyakorlatban', Médiakutató (Fall edn 2006).

Sólyom, L., A személyiségi jogok elmélete (Közgazdasági és Jogi Könyvkiadó 1983).

Middlemiss, S., Warner, S., 'Is there still a hole in this bucket? Confusion and misrepresentation in passing off' (2006) 2 Journal of Intellectual Property Law \& Practice 131-142.

Szalai, P., 'A védjegy megkülönböztetőképességének elvesztése' (2010) 5 Iparjogvédelmi és Szerzői Jogi Szemle 8-33.

Törő, K., A személyiség jogi védelme (Közgazdasági és Jogi Könyvkiadó 1979).

Vida, S., 'Az Európai Bíróság gyakorlatának hatása a magyar védjegyjogra' (2010) 3 Iparjogvédelmi és Szerzői Jogi Szemle 75-78.

Waelde, Ch., Laurie, G. (et al), Contemporary Intellectual Property ( $3^{\text {rd }}$ ed, Oxford University Press, 2014).

Walsh, Ch., 'Are personality rights finally on the UK agenda?', (2013) 1 European Intellectual Property Review 253-260. 